Int. J. Electrochem. Sci., 13 (2018) $4298-4308$

\title{
A Comparative Study of Critical Pitting Temperature (CPT) of Super Duplex Stainless Steel S32707 in NaCl Solution
}

\author{
Xiu-qing Xu ${ }^{1,2, *}$, Mifeng Zhao ${ }^{3}$, Yao-rong Feng ${ }^{1,2}$, Fa-gen Li $^{1,2}$, Xiang Zhang ${ }^{1}$ \\ ${ }^{1}$ Tubular Goods Research Institute of China National Petroleum Corporation, Xi'an Shaanxi 710077 \\ ${ }^{2}$ State Key Laboratory of Performance and Structural Safety for Petroleum Tubular Goods and \\ Equipment Materials, Xi'an Shaanxi 710077 \\ ${ }^{3}$ Oil and Gas Engineering Research Institute of PetroChina Tarim Oilfield Company, Korla Xinjiang \\ 841000 \\ *E-mail: xuxiuqing00@126.com, xuxiuqing@ cnpc.com.cn
}

doi: $10.20964 / 2018.05 .173$

Received: 6 January 2018 / Accepted: 15 March 2018 / Published: 10 April 2018

In this study, the critical pitting temperature (CPT) of super duplex stainless steel UNS S32707 was compared using potentiodynamic, potentiostatic techniques, EIS and new electrochemical noise method. The results revealed that the CPT of S32707 is between $55-65{ }^{\circ} \mathrm{C}$ for potentiodynamic polarization and $64{ }^{\circ} \mathrm{C}$ for potentiostatic polarization, respectively. The pitting corrosion of S32707 occurs at about $65^{\circ} \mathrm{C}$ for EIS method and the CPT value is between $58-65{ }^{\circ} \mathrm{C}$ for electrochemical noise method.

Keywords: critical pitting temperature, super duplex stainless steel UNS S32707, electrochemical methods, $\mathrm{NaCl}$ solution

\section{FULL TEXT}

(C) 2018 The Authors. Published by ESG (www.electrochemsci.org). This article is an open access article distributed under the terms and conditions of the Creative Commons Attribution license (http://creativecommons.org/licenses/by/4.0/). 